\title{
Proverbial Oppression of Women in Yoruba African Culture: A Philosophical Overview
}

\author{
Oladele Abiodun Balogun \\ Department of Philosophy \\ Olabisi Onabanjo University, Nigeria \\ balogundele@yahoo.com
}

\author{
Thought and Practice: A Journal of the Philosophical Association of Kenya (PAK) \\ New Series, Vol.2 No.1, June 2010, pp.21-36 \\ thoughtandpractice@gmail.com OR thoughtandpractice@uonbi.ac.ke \\ http://ajol.info/index.php/tp/index
}

\begin{abstract}
This paper posits that there are elements of oppression in some of the Yoruba proverbs that relate to women. It argues that these proverbs violate the rights and dignity of women, and that they are indicators of discrimination against women in Yoruba culture. The paper further argues that the most fundamental but neglected aspect in gender discourse lies in the proverbial resources of the community. The paper provides textual evidence of proverbial oppression of the feminine gender in Yoruba culture, and also underscores their pernicious effects on the struggle for gender balance. The paper contends that there is an urgent need to review the assumptions underlying these proverbs.
\end{abstract}

\section{Introduction}

The question of gender has spawned considerable debate in contemporary African studies. The debate is no longer on whether or not African women are oppressed; nor is it on whether or not there is gender imbalance in the African cultural milieu. There is consensus on the pervasiveness of these problems in Africa. However, female 
autonomy, solidarity and empowerment currently occupy a special place in gender and development discourse in Africa. The cry of feminists in Africa today, for the most part, concerns how the crises of women's empowerment can be resolved, since there is the strong conviction that the resolution of the problem will lead to a form of development in the society (Balogun 2006, 118).

Various women liberation movements have evolved, and there has also been considerable scholarly effort to expose the sources and dangers of the oppression of women, restoring the identity and dignity of women, and empowering them for national development. While such efforts are commendable, it is apposite to note that substantial success has not been recorded in the drive towards the empowerment of women. This is because one of the salient causes of gender imbalance in Africa has not been properly diagnosed in gender and feminist studies. This work reflects on this salient problem, namely, the pervasiveness of oppressive proverbs, and on how it can be realistically overcome.

The oppression of women is fostered in Africa, in fact globally, through cultural vehicles such as proverbs. Though the use of proverbs may differ from society to society, what is common to proverbs everywhere is that they touch on a wide array of human concerns and activities. Proverbs are highly regarded in the thinking and communication process of Africans as a whole. Generally, the social functions of proverbs in African cultures have been well documented in folklore scholarship. However, little attention has been directed towards the relationship between proverbs and the oppression of women, and, more specifically, how proverbs, as a discourse in which females are portrayed based on stereotypical gender roles and perceptions, continue to frustrate the current efforts towards gender-sensitization and the attendant empowerment of women in the continent. As Temitope Balogun correctly notes, "proverbs have served as a major avenue for the continued perpetration of gender discrimination among the Africans" (Balogun 2005, 39).

This paper provides textual evidence and analysis of Yoruba ${ }^{1}$ proverbs that demean

\footnotetext{
${ }^{1}$ The Yoruba constitute one of the major ethnic and cultural groups in South West Nigeria, West Africa. The Yoruba are dispersed throughout the world as they are found in sizeable populations in the
} 
women. The reason for the choice of Yoruba proverbs is for specificity of claims, given my intimate familiarity with the Yoruba language. In the course of this paper, I shall examine some proverbs implicit with gender prejudice against the female folk. Subsequently, I will attempt to re-construct some of the proverbs identified, with a view to making them gender-neutral, thereby contributing to the restoration of the dignity of African women. In the endeavour to overcome the crisis of the proverbial oppression of women, the roles of men, women, the youth and the government are also highlighted.

\section{Conceptualizing the Proverbial Oppression of Women In Yoruba Culture}

In his paper, "The Derogation of Masculinity in Yoruba Proverbs", Joshua Abiodun Ogunwale (1998) asserted the existence of the proverbial oppression of men as against women in Yoruba culture. He argued that judging from the meaning, potentials and interpretations of some masculine metaphors in Yoruba proverbs, it is the female folk who actually occupy an advantaged position (Ogunwale 1998, 103). In establishing his position, Ogunwale discusses some Yoruba proverbs that attribute negative characteristics to the male folk. He cites a considerable number of proverbs that demean masculinity, especially by attributing to it undesirable character traits such as disgracefulness, insolence, disobedience, indolence and absurdity. Nevertheless, it is my view that in the Yoruba culture, on matters of language and gender relations, the proverbial oppression of women is more pronounced than that of men.

Discourses on gender occupy a central place in contemporary scholarship. Unlike sex which is biologically defined, gender is socially constructed and has changing variables. Gender refers to the social relationships between men and women and the way those relationships are made. It can also be described as the division of society into biological, occupational and social roles. Such roles include reproduction,

Republic of Benin, Togo, Ivory Coast and Ghana in West Africa. Yoruba culture also thrives notably in West Indies, South Africa, South America, Brazil and Cuba. Each of the Yoruba cultural groups in the Diaspora still trace their ancestral roots to Oduduwa in Ile-Ife, South West Nigeria. 
production, community management, politics, and participation in other domestic and civic aspects of life (Aina 2006, 1).

Western feminist discourses see this conception of woman and gender as universally binding. However, some scholars with an African orientation have challenged this assumption, arguing that gender is a socio-cultural construct whose meaning cannot be understood outside specific cultural contexts. The argument of Oyeronke Oyewunmi is pertinently fascinating in this regard. She sees the central challenge of African gender studies as that of how to rethink the two basic categories of woman and gender and avoid applying Western feminist concepts and meanings in the attempt to interpret African realities:

The fact that Western gender categories are presented as inherent in nature (of bodies) and operate on dichotomous, binarily opposed male/female, man/woman duality in which the male is assumed to be superior and therefore the defining category, is particularly alien to many African cultures. When African realities are interpreted based on these Western claims, what we find are distortions, obfuscations in language and often a total lack of comprehension due to the incommensurability to social categories and institutions (Oyewunmi 1997, 318-319).

Oyewunmi's view above is in consonance with my position that gender crisis in Yoruba thought is a consequence of Western experience, a view I have elsewhere argued for (Balogun 1999, 42-52). However, Oyewumi's argument deserves further comment. Using the traditional Yoruba society to illustrate her position, she argues that the operational logic of Yoruba society is not rooted in a gender map that takes biology or the visual as the foundation for the social. In other words, the nature of one's anatomy does not define one's social position. She argues that the traditional Yoruba family is a non-gendered family. By this she means that kinship roles and categories are not gender-differentiated. This is so because power centers within the family are diffused and not gender specific: the body is not always considered for gender categorization. The fundamental organizing principle of social roles within the family is seniority and not gender. In contrast to the West, she argues, social hierarchy among the Yoruba is determined by social relations, whereby the cultural model is grounded on 'seniority' based on chronological age. 'Seniority is not just a matter of privilege in everyday life; it is also responsibility' (Oyewunmi 2005, 108). Oyewunmi writes: 
Seniority is the social ranking of persons based on their chronological ages. Hence the words egbon refers to the older sibling and aburo to the younger sibling of the speaker regardless of gender. The seniority principle is dynamic and fluid; unlike gender, it is not rigid or static (Oyewunmi 2006, 317).

Given Oyewunmi's insightful observations, there is the temptation to think that since gender crises was absent in traditional Yoruba African conception of family, ipso facto there was no oppression of women in traditional Yoruba culture. While Oyewunmi's position implicitly assumes the denial of women's oppression in traditional Yoruba African society, I think non-genderization in the Yoruba thought system does not logically entail non-oppression of women. The proverbial linguistic resources of the Yoruba can be used to substantiate this position. Proverbial oppression here is construed as cruel and unfair pithy sayings that derogate the dignity, integrity, rights and freedom of the women folk.

\section{Proverbial Oppression of Women in Yoruba African Culture: Some Illustrations}

Proverbs are used not only to reflect on established norms, but also as a means of preserving a community's memory of past events. As is true of many cultural groups, the Yoruba of the South-Western geopolitical zone of Nigeria hold the use of proverbs in high esteem. There are different sets of proverbs that accompany various activities, events, things and ideas (Daramola 2004; Salami 2004; Asiyanbola 2006). Among the Yoruba, proverbs can take corrective, didactic, abusive or even eulogistic forms. However, with respect to women, proverbs have consistently taken a derogatory garb. As we shall show shortly, most of these proverbs reveal that women's safety, well-being and rights are of little interest to the male folk. The proverbs examined below are for the most part from my observation of communication among the male and female folk in Yoruba society. I attempt to hermeneutically translate the proverbs literally.

(i) Pashan ta fi na yale, oun be laja fun'yawo

("The whip that was used to beat the first wife is kept for the second wife").

The underlying assumption of this proverb is that a woman is regarded as a child, to 
be disciplined anytime she errs, and that a man has the right to beat his wife (wives). The proverb also presupposes that a man has the right to marry more than one wife, and that the second wife should not expect preferential treatment over the first wife. This proverb allows for blatant brainwashing of women, with a view to getting them to view themselves as inferior to men.

(ii) Baa fi gbogbo ile nla jin kolekole, kope o ma jale die kun; bi a si fi gbogbo odede jin iyawo agbere, kope o ma tara re f'ale

("Give a mansion to a thief - that does not prevent him from stealing; give a promiscuous wife all you have in a beautiful house - that does not preclude her from selling herself cheaply to a paramour").

This proverb portrays women as unpredictable with regard to sexual and marital issues. Yet according to this proverb, some women are promiscuous while others are not. Yoruba tradition allows polygamy, but perceives polyandry with disdain. The proverb is an expression of distrust and a deterministic conception of the woman.

(iii) Itakun l'obinrin yoo maa fa kaa ni

("Women are climber plants that overrun any available space").

The expression in this proverb is figurative. It compares the nature of women to that of a plant which has its roots in one place and its branches in another. The proverb pictures women as people of unpredictable character, with a natural propensity to be involved in multiple affairs at the same time (Daramola 2007, 127). The proverb implies that women by nature are unreliable, and by virtue of this, they "hook up" with the best suitor in conjugal relationships. In short, it presents women as covetous. It thus exclusively ascribes a psychological trait to women without compelling evidence for it.

(iv) Bi koba ni dii, obinrin kii je Kumolu, bi obinrin ba je Salawu, yoo san wo ori

("Without any reason, a woman cannot be called Kumolu, if a woman bears Salawu, then she will pay tax").

Naming of children in traditional Yoruba society is segregative. It is believed that there are some names that a female child cannot bear unless exceptions are made for her. The proverb reveals this, as it mentions the discriminatory tax involved when a female child is given the name "Salawu", which is reserved for male children.

(v) Bi obinrin b' ape nile, aje londa 
("If a lady stays too long in the house, she becomes a witch").

This proverb is a reflection of the Yoruba conception of long spinsterhood. It is expected that a lady will be married by a specific age, and when the contrary is the case, she will begin to lose respect, as indicated by reference to her as a witch. This is also the case when a woman gives birth to female children without having male offspring: she and the girls will be referred to as witches. Another proverb that captures this negative perception of women in Yoruba culture is:

(vi) kaka ko san lara iya aje, ofi gbogbo omore b'obinrin, eye wan yi lu eye

("Instead of it getting better for the witch, all her children are girls, the birds are thus multiplying") (Bello-Olowookere 2005, 44).

It is important to note at this point that not all Yoruba proverbs are abusive to women; some are selective of certain categories of women. Consider the following proverb:

(vii) Obun-un r'iku tiran mo; o ni ojo ti oko oun ti ku oun ko we

("The filthy woman saw the husband's death as an excuse; she said since her husband died, she has not taken bath").

This proverb is not directed to all women, but only to an untidy woman who takes the customary Yoruba mourning period for her husband as an excuse for not adhering to the requirements of personal hygiene. So also is proverb (viii) below, which is meant to scorn widows for their alleged bad destinies that shorten their husbands' lives:

(viii) Ori obinrin ti yoo su 'po kii je ki oko ye

("A woman destined to marry a widower will not allow the husband to survive").

(ix) Esin obìnrin soro gùn, o le gbéni subù.

("It is not good for a man to climb on his wife's horse because he can fall to his death") (Asiyanbola 2007, 69).

The horse metaphor in this proverb is used to represent the whims of one's wife. The proverb is a warning that men who go by the whims of their wives cause their own downfall. Among the present-day couples in Nigeria, for example, the age of chivalry has been re-enacted, in that some men will not use their discretion in the absence of their wives. The members of such men's extended families may decide to disown them and their nuclear families. The above proverb is, however, gender-biased against women, because it forecloses the supportive and proficient advice women are capable of giving to their husbands, associates, friends and relatives (whether male or female). 
This proverb portrays women as jealous. Though this is partly true, the tendency is not limited to women, as experience shows men to be jealous as well.

(xi) Eni ti ofe arewa fe iyonu, eni gbogbo ni i ba won tan (Delano 1976, 134)

("He who marries beauty marries trouble; everybody claims relationship with her").

This is an unfair indictment of the beautiful feminine folk. There is no established causal connection between physical beauty and faults in character. This proverb confuses, perhaps even equates, elegance and admiration with a promiscuous lifestyle.

(xii) Obinrin ko se finu han

("Secrets should not be revealed to a woman") (Ajibola 2005, 26).

This proverb implies that women naturally have the tendency to divulge secrets. It explains, partly or wholly, why women are not always involved in decision making, despite their indispensable contribution to society.

(xiii) Awo egungun lobinrin lese, awo gelede lobinrin lemo,bobinrin foju koro, oro a gbe.

("Women can only engage in the cult of egungun, (masquerade); they can do well participating in the cult of gelede, but if a woman sees the cult of oro, she will be consumed").

This proverb is a pointer to the fact of unequal gender participation in religious matters. There are some cultic practices that are the preserve of men, including agemo, oro and eyo, while there are some that women are allowed to participate in, such as egungun, oroyeye and gelede. This religious structure of the Yoruba is chauvinistic.

(xiv) Owu ti iya gbon, lomo ran.

("The child takes after the behaviour of the mother").

This is indicative of the fact that whenever men want to discipline their children for unruly behaviour, even when the causes can be traced to the negligence on the part of men, the whole blame will be placed on women. Any character deficiency exhibited by a child is linked to the shortcomings of the mother.

(xv) Olobe lo loko

("She that prepares the tasty soup owns the husband").

The import of this proverb is that marriage is not an automatic guarantee that a woman possesses the heart of her husband; rather, it is how good she is at preparing 
tasty dishes for her husband that determines whether she owns the man or not. Thus women are at the mercy of men's appetite for delicacies.

(xvi) Bi a ba maa gb'omo rere jo, iyawo rere laa koko gbe jo

("Dancing with a good wife is a precondition for dancing with a good child").

The above proverb is used to encourage women to endeavour to please their husband so that their children can find favour with them. It is believed in Yoruba culture that good wives are pointers to good children and good families. Love and hatred are contagious. The honesty and love shown by a woman to her husband are usually reciprocated on their children.

(xvii) İyàwó tí a fe lójú ijó ìran nií owòlo

("A woman whom one meets at a dance party an marries will slip away at the glimpse of a better suitor").

This proverb highlights the perceived unreliability of women, especially wives whose meeting point with their husbands was a social function such as a ball. The Yoruba society is patriarchal (it is the man that woos and marries the woman and not the other way round), and emphasis is placed not only on the woman's character, but also on how she was dressed and where she was when her husband first met her.

(xviii) Obìnrin bímo fún ni ko pé ko mo pani, obìnrin ko bímo fúnni ko pe koma pani.

("Whether a woman has a child or not for her husband does not prevent her from killing him").

This is used as a warning to men that they should not gain false security from the fact that their wives have borne children for them - that bond may not be as strong as the husbands might think. This proverb shows the men folk's distrust for women.

(xix) Obinrin sowa nù o ni oun ko lori oko

("A woman is bereft of good behaviour, and she complains of not being destined to have a good husband") (Asiyanbola 2007, 73).

This proverb sees women of questionable character as the only ones exposed to marital problems, which implies that men are free from blame whenever such problems occur.

(xx) Kobìnrin tato rin kokùnrin tatorin, enikan ní láti lomi leyìn ese ju ara won

("Let a woman and a man walk while urinating: one of them will have messy feet 
much more than the other") (Asiyanbola 2007, 75).

This indicates that the Yoruba society is highly patriarchal, with women being regarded as inferior to men, despite the fact that when it comes to the realm of spiritual powers, women are esteemed as the owners of the world (awon iya alaye) because of the general belief that they possess superior clairvoyant and spiritual powers.

(xxi) Obinrin ti ko dara nile oko re, ko lee dara nile omo re, iyawo omo re ni yoo ma ba s'orogun

("A woman that is bad in her husband's house cannot be good in her son's house: she will become a rival to her son's wife") (Daramola 2007, 128).

This proverb highlights the alleged symmetrical relationship between being a good wife and being an impeccable mother-in-law. It is intended to serve as a caution to women folk in general. It is oppressive because it fails to acknowledge the repression of wives by some husbands, and the implication of such behavior on the possibility of playing the roles of good father and good father-in-law.

(xxii) Isense ti o fi de ihin kii kuro lara pansaga obinrin

("The saying "your mannerism brought you here" will always be a stigma on a promiscuous woman").

While this is a welcome moral nugget, it remains oppressively biased. Just like proverb (xxi) before it, the oppressiveness of this proverb derives from the absence of corresponding proverbs cautioning against men's nefarious behaviour. The reason for this is that in Yoruba culture, men are seen as "lords" in marriage.

\section{Effects of proverbial oppression of women}

The proverbial oppression of women in Yoruba African culture, as outlined above, has some pernicious effects on the identity, dignity, rights, freedom and empowerment of women in this cultural milieu. The perception of women's personality, their strengths and weaknesses, their dignity, by the society and by themselves, is, among other things, the result of the way they are portrayed in proverbs. The fundamental impression given by some of these proverbs is that the nature of women distinctly differs from that of men. This has brought about discrimination against women in Yoruba African culture, especially in important 
issues that concern their welfare and happiness. For instance, these oppressive proverbs have undermined the complimentary contribution of women in marriage. Where trust, openness, honesty, compassion and love ought to govern marriage, the picture painted by many Yoruba proverbs, and which they encourage men to nurture, is that of the reign of suspicion, secrecy, dishonesty and carefree attitudes. All these have resulted in rampant divorce in Nigeria. Thus proverbial oppression fosters women's dependence, and frustrates the efforts of empowering women.

Despite the awareness of women's efforts to liberate themselves, many Yoruba men use proverbs and other aspects of tradition to justify their chauvinism. The problem with this oppressive proverbial orientation is that it is fallacious. The appeal to proverbs is an argumentam ad verecundiam, that is, an unwarranted appeal to authority. Proverbs are human sayings, and as such some of them are misleading. They are dogmatic formulas, often authored by men (males), to foster their hegemonic masculinity. This worrisome situation calls for an urgent reconstruction of oppressive Yoruba proverbs against women, as will be attempted in the following section.

\section{Reconstructing oppressive Yoruba proverbs against women}

Due to the general view of folklore as a self-contained authentic peasant culture from which all references to changing social realities must be excluded, African oral literature has been largely insulated against criticism (Yitah 2006, 237). African proverbs in particular have been viewed as sacred texts that must remain unchanged. This fact has dire ramifications for the struggle against the proverbial oppression of women. In Owomoyela's words, women are “expected to accommodate the men's libertine [meaning bawdy] talks, even about [themselves], with good humor and demureness" (Owomoyela 1972, 752). Owomoyela refers here to Yoruba men's use of proverbs that express crudity and sex without attracting "the stigma of uncouthness traditionally associated with such talk in the genteel Western World" (Owomoyela 1972, 752). We disagree with the way Owomoyela takes for granted the proverbial oppression of women in the Yoruba cultural milieu. Such oppressive proverbs must be resisted and/or reconstructed through proper education and rigorous commitment to the feminine course. 
Given some of the inadequacies that dogmatically spawn some of African traditional proverbs, Raji-Oyelade has called for a post-proverbial exercise in contemporary African discourse. This involves a reconstructive engagement with some African proverbs considered to be out of date. He refers to this exercise as "a normative rupture in the production [and interpretation] of this traditional verbal genre", and it results in the emergence of "'new' proverbs with new forms, new meanings, and, perhaps, new values" (Raji-Oyelade 1999, 75). Raji-Oyelade's call is very significant to our discussion on oppressive Yoruba proverbs. The import is not that women would have to renounce traditional proverbs in the course of this "rupture"; rather, it would be expected of them to question whether or not existing proverbs accurately present their full personhood.

Yitah also correctly notes that in order to criticize these oppressive proverbs, the (female) interrogator has to look beyond the individual (male) user's immunity, and examine the collective image that the proverb presents of women(Yitah 2006, 237). In strong agreement with Raji-Oyelade and Yitah, I shall attempt to make proverbs reveal the reality of African women's liberated lives rather than the ideals of traditional patriarchal society. By so doing, it is expected that traditional patriarchal proverbial representations will gradually be deconstructed to allow for the true liberation and empowerment of women. Against this background, let us attempt to de/reconstruct the earlier identified oppressive Yoruba proverbs. Given the limited scope of this paper, this de/reconstructive exercise has utilised only some of the oppressive proverbs earlier examined.

Proverb (i), ("The whip that was used to beat the first wife is kept for the second wife"), facilitates the blatant brainwashing of women so as to view themselves as inferior to men. One might wonder why there is no proverb such as:

Pashan ta fi na oko kini, owa ni pepe fun oko keji

("The whip that was used to beat the first husband is on the shelf for the second husband").

To make a case for a post-proverbial like this would be grandeur feminine delusion, at least for two major reasons. First, Yoruba African society is not polyandric, and the meaningfulness of this post-proverbial can only be determined within such a context. Second, to build a case for such a post-proverbial would be begging the question of proverbial oppression, as it would only swop the positions of the oppressor and the 
oppressed. Consequently, I recommend that this proverb be expurgated from the Yoruba oral tradition.

A reconstruction of proverb (ii) might take the form:

Baa fi gbogbo ile nla jin kolekole, kope o ma jale die kun; bi a si fi gbogbo odede jin oko agbere tabi iyawo onisekuse, kope o ma se sina ("Give a mansion to a thief - that does not prevent him from stealing; give a man or woman all you have in a beautiful house - that does not preclude him or her from being promiscuous").

This is neither a counter abusive accusation nor a one-sided prescription as it was in its original form. Rather, it appears more or less like a fair proverbial portrayal, which actually depicts both the men and women folk as vulnerable when it comes to issues of marital infidelity.

Proverb (iii) implies that covetousness is an incurable disease, but that it is to be found only in women. If indeed covetousness is an incurable disease, and given human nature generally, the proverb should include both sexes in its description. The reconstructed proverb would then be:

Itakun l'eniyan yoo maa fa kaa ni

("Humans are climber plants that overrun any available space").

Proverb (xvii) is evidently one sided. However, it is possible to construct a version of it that would neutralize the prejudice against women inherent in it, as in the following version:

Enikeni tí a fe lojú ijo iran ni o wo loo

("Any partner met at a dance party is a bird that can fly away any time").

This shows that infidelity is not restricted to women.

Proverb (xviii) warns men against deriving false security from the fact that their wives have borne children for them. The proverb may be an exaggeration, communicating the truism that a wife who will hate her husband will do so irrespective of the bond she shares with him through being parents to their children. This proverb can also be re-constructed to be more objective:

Abimo fún ara eni kope ki a ma pa ara eni; a o bimo fun ara eni, kope ki a ma pa ara eni.

("Whether there is offspring between a couple or not does not prevent either of the parties persecuting the other"). 
This is to say that disappointment in marriage can come from either of the partners.

Proverb (xix) brings to the fore the Yoruba belief in ori (bearer of destiny). The proverb reveals that the wife who is of bad behaviour finds an excuse or solace in her destiny that she claims does not provide a good husband for her, not realizing that she has bad behaviour ("bad inner head"). Yet one wonders why there is no such proverbial reprimand for immoral husbands, seeing that it is not only the woman that can have unacceptable behaviour. A reconstruction of this proverb that takes into consideration the two sexes is necessary:

Eniyan so wa nù o ní oun ko lorí aya tabi oko.

("One is bereft of good behaviour, yet one complains of not being destined to get either a good wife or husband").

\section{Conclusion}

One of the orientations transmitted through proverbs is the conservative and oppressive view of women. Though not all African women are oppressed and not all proverbs demean women, for the most part, many Yoruba proverbs clearly point to the oppression of women in Yoruba society. Male users of these proverbs consider them witty rather than offensive and oppressive, while their female referents feel humiliated by them. The fact is that it is not only women that should be blamed for problems of all sorts such as divorce, sexual immorality, extravagance and dishonesty. We should therefore have proverbs that reprimand or warn both sexes. The oppressive picture of the nature of women painted by many Yoruba proverbs must be critically re-examined.

The struggle for women's empowerment and development may not come to fruition unless urgent attention is paid to a deconstruction and reconstruction of proverbs in order to restore African women's dignity and empower them for contemporary challenges. However, we should not be oblivious to certain obstacles that may be in the way of these efforts. First, there is the likelihood of resistance from many African elders who see indigenous proverbs as sacrosanct. Second, there is the tendency of scholars to make the process of re-construction unnecessarily complex. Third, there is the possibility of slowness to grasp the significance of the project on the part of the majority of contemporary Africans. 
These challenges are not insurmountable. The resistance of elders would be phased out in the light of contemporary values and orientations. With regard to the second challenge, African scholars working in this area would be urged to present their research findings in forms easy to comprehend in order to facilitate the education of the people. The third challenge can be overcome by intensive collaborative efforts of the academic community, government and Non Governmental Organizations. Through awareness programmes, men must be made to understand that women are their complements who must enjoy equal rights with them. The average educated Yoruba man can learn to break free from the abusive clutches of proverbs through proper information. Furthermore, as we educate our women and men on the need for wholesome gender relations, we must also help our youth to recognize that they have a key role to play in promoting complementary gender interactions in contemporary Africa. The male youth must start nurturing positive orientations and dispositions towards their female counterparts in order to catalyze the development of society as a whole.

\section{References}

Aina, O.I. 2006. "Sex Versus Gender". Paper presented at a workshop on Gender Disaggregation at the Obafemi Awolowo University, Ile-Ife.

Ajibola, J.O. 2005. Owe Yoruba. Ibadan: Ibadan University Press.

Asiyanbola, A.A. 2007. "A Syntactic and Semiotic Analysis of Some Yoruba Sexist Proverbs in English Translation: Need for Gender Balance". Nebula, Vol.4 No.3, pp.70-83.

Balogun, O. 1999. "Gender Crises in Yoruba Thought: An Aftermath of Western Experience". Journal of Arts and Humanities, Vol.1 No.1, pp. 42-52.

--. 2006. "Crises of Women Empowerment in Nigeria: The Males' Contribution". Journal of Policy Studies, Vol.2 No.1, pp.114-120.

Balogun, T. 2005. "A Semantic Enquiry into Yoruba Proverbs and Gender Discrimination". Journal of Arts and Humanities, Vol.2 No.1, pp.39-43.

Bello-Olowookere, G.A.B. 2004. Egberun Ijinle Owe Yoruba Ati Itumo won niEde Geesi (1000 Yoruba Proverbs and Their Translations in English). Lagos: Concept Publications Ltd.

Daramola, A. 2004. "Yoruba Proverbs in the Perspectives of Music". Proverbium, Vol.21, pp.27-34.

--. 2007. "Sokoro Sakara: A Contextual and Gender Analysis of Some Offensive Yoruba Proverbial Songs". Nebula, Vol.4 No.4, pp.124-138.

Delano, I. 1976. Owe L'esin Oro: Yoruba Proverbs: Their Meaning and Usage. Ibadan: Oxford University press.

Ogunwale, J.A. 1998. "The Derogation of Masculinity in Yoruba Proverbs". Nordic 
Journal of African Studies, Vol.7 No.1, pp.103-113.

Owomoyela, O. 1972. "The Sociology of Sex and Crudity in Yoruba Proverbs". Proverbium, Vol.20, pp.750-761.

Oyewumi, O. 1997. The Invention of Women: Making an African Sense of Western Gender Discourses. Minneapolis: University of Minnesota Press.

--. 2006. "Conceptualizing Gender in African Studies". The Study of Africa: Disciplinary and Interdisciplinary Encounters, Vol.1. Zeleza, Paul Tiyambe ed. Dakar: CODESRIA Book Series.

Oyewumi, O. ed. 2005. African Gender Studies: A Reader. New York: Palgrave Macmillan.

Raji-Oyelade, A. 1999. "Postproverbials in Yoruba Culture: A Playful Blasphemy". Research in African Literatures, Vol.30 No.1, pp. 74-82.

Salami, Y.K. 2004. "Yoruba Proverbs and Democratic Ethos". Proverbium, Vol.21, pp.315-328.

Organization of African Unity. 1981. The African Charter on Human and Peoples' Rights. Addis Ababa: The Organization of African Unity.

Yita, H. 2006. “Throwing Stones in Jest: Kasena Women's 'Proverbial' Revolt". Oral Tradition, Vol.21 No.2, pp.234-243. 